\title{
Implementasi Pendidikan Karakter dalam Pembelajaran Matematika SMP di Kota Yogyakarta
}

\author{
Indah Pertiwi $^{1}{ }^{*}$, M. Marsigit ${ }^{1}$ \\ ${ }^{1}$ Program Studi Pendidikan Matematika, Program Pascasarjana, Universitas Negeri Yogyakarta. Jalan \\ Colombo No. 1, Karangmalang, Yogyakarta 55281, Indonesia. \\ * Corresponding Author. E-mail: ind4h.pertiwi@gmail.com \\ Received: 18 October 2016; Revised: 2 November 2017; Accepted: 9 November 2017
}

\begin{abstract}
Abstrak
Penelitian bertujuan untuk mendeskripsikan implementasi, faktor pendukung dan penghambat penerapan pendidikan karakter dalam pembelajaran matematika SMP di Kota Yogyakarta. Penelitian ini merupakan penelitian evaluasi model discrepancy model dengan pendekatan kuantitatif dan kualitatif. Penelitian melibatkan sampel sebanyak 22 SMP untuk pengumpulan data kuantitatif dan 6 SMP untuk pengumpulan data kualitatif. Hasil evaluasi dapat disimpulkan bahwa implementasi pendidikan karakter dalam pembelajaran matematika SMP di Kota Yogyakarta termasuk dalam kategori cukup. Adapun faktor pendukung adalah (1) visi dan misi sekolah; (2) adanya peraturan dan tata tertib yang telah diatur sekolah, (3) dukungan dan kerjasama yang baik antar warga sekolah; (4) kondisi siswa yang memiliki dasar karakter baik; (5) contoh perilaku positif guru sebagai teladan. Sedangkan faktor penghambat adalah (1) guru belum memiliki pemahaman yang memadai tentang konsep pendidikan karakter dalam pembelajaran matematika; (2) guru mengalami kesulitan dalam mengidentifikasi nilai karakter dari kompetensi dasar pada mata pelajaran matematika; (3) guru belum dapat mengimplementasikan pendidikan karakter yang terintegrasi dalam pembelajaran matematika dengan baik; (4) sarana dan prasarana yang belum lengkap; (5) dokumentasi penilaian sikap siswa masih lemah.
\end{abstract}

Kata Kunci: implementasi pendidikan karakter, pembelajaran matematika, evaluasi.

\section{Character Education Implementation in Mathematics Teaching and Learning of Junior High School in Yogyakarta}

\section{Abstract}

The aim of this research was to describe the implementation, supporting factors and obstacles the implementation of character education in mathematics teaching and learning of junior high school in Yogyakarta. This research is an evaluation research discrepancy model with the quantitative and qualitative approach. The study involved 22 samples of SMP for quantitative data collection and 6 SMP for qualitative data collection. The results from this study revealed that character education implementation in mathematics teaching and learning of junior high schools in Yogyakarta was good. Supporting factors were: (1) the vision and mission of the school; (2) ground rules that have been designed by the schools; (3) support and cooperation among school members; (4) student's condition who have a basic good character; and (5) examples of positive behavior of teachers as role models. Obstacles were: (1) teachers do not have enough understanding of character education especially in the implementation in mathematics teaching and learning processes; (2) teachers have difficulties to identify the character values from the basic competence of mathematics; (3) teachers have not been able to implement character education integrated to mathematics teaching and learning processes properly; (4) poor teaching and learning facilities in some schools; and (5) poor documentation of students' character assessment.

Keywords: character education implementation, mathematics teaching and learning, evaluation

How to Cite: Pertiwi, I., \& Marsigit, M. (2017). Implementasi pendidikan karakter dalam pembelajaran matematika SMP di Kota Yogyakarta. Jurnal Riset Pendidikan Matematika, 4(2), 153-165. doi:http://dx.doi.org/10.21831/jrpm.v4i2.11241

Permalink/DOI: http://dx.doi.org/10.21831/jrpm.v4i2.11241 


\section{Jurnal Riset Pendidikan Matematika, 4 (2), 2017 - 154}

Indah Pertiwi, M. Marsigit

\section{PENDAHULUAN}

Pendidikan karakter merupakan upaya untuk membantu mempersiapkan generasi bangsa yang berkualitas dan siap menghadapi tantangan masa depan. Kemendiknas (2010b, p.1) menyatakan bahwa pendidikan dianggap sebagai alternatif yang bersifat preventif karena pendidikan membangun generasi baru bangsa yang lebih baik. Sebagai alternatif yang bersifat preventif, pendidikan diharapkan dapat mengembangkan kualitas generasi muda sehingga dapat menekan timbulnya masalah budaya dan karakter bangsa. Menurut Santrock (2014, p.245), "Character education is a direct approach to moral education that involves teaching students basic moral literacy to prevent them from enggaging in immoral behavior and doing harm to themselves or other". Hal ini berarti bahwa pendidikan karakter adalah pendekatan langsung pada pendidikan moral, yakni mengajari siswa dengan pengetahuan moral dasar untuk mencegah mereka melakukan tindakan tak bermoral dan membahayakan orang lain dan dirinya sendiri. Sehingga Arthur (2003, p.86) menyatakan bahwa, "Teachers are expected to teach certain skills, understandings and attitudes which are tools for living" yang berarti bahwa guru diharapkan untuk mengajarkan keterampilan tertentu, pemahaman dan sikap yang merupakan bekal untuk hidup.

Pada tahun 2010 pemerintah melalui Kementrian Pendidikan Nasional mencanangkan Kebijakan Nasional Pembangunan Karakter Bangsa Tahun 2010-2025. Kebijakan tersebut dilatarbelakangi oleh situasi dan kondisi karakter bangsa yang memprihatinkan (Republik Indonesia, 2010, p.2). Selain itu, ditegaskan pula dalam lampiran undang-undang Republik Indonesia Nomor 17 Tahun 2007 tentang Rencana Pembangunan Jangka Panjang Nasional 20052025 bahwa misi pertama dari delapan misi guna mewujudkan pembangunan nasional yakni mewujudkan masyarakat berakhlak mulia, bermoral, beretika, berbudaya, dan beradab berdasarkan falsafah Pancasila adalah memperkuat jati diri dan karakter bangsa melalui pendidikan yang bertujuan membentuk manusia yang bertaqwa kepada Tuhan Yang Maha Esa, mematuhi aturan hukum, memelihara kerukunan internal dan antarumat beragama, melaksanakan interaksi antarbudaya, mengembangkan modal sosial, menerapkan nilai-nilai luhur budaya bangsa, dan memiliki kebanggaan sebagai bangsa Indonesia dalam rangka memantapkan landasan spiritual, moral, dan etika pembangunan bangsa (Republik Indonesia, 2007, p.5). Misi tersebut sejalan dengan Undang-undang Republik Indonesia Nomor 20 Tahun 2003 pasal 3 tentang Sistem Pendidikan Nasional yang menjelaskan bahwa pendidikan nasional berfungsi mengembangkan kemampuan dan membentuk watak serta peradaban bangsa yang bermartabat dalam rangka mencerdaskan kehidupan bangsa, bertujuan untuk mengembangkan potensi peserta didik agar menjadi manusia yang beriman dan bertaqwa kepada Tuhan Yang Maha Esa, berakhlak mulia, sehat, berilmu, cakap, kreatif, mandiri, dan menjadi warga negara yang demokratis serta bertanggung jawab (Republik Indonesia, 2003, p.28). Menindaklanjuti hal tersebut Menteri Pendidikan Nasional Republik Indonesia memberlakukan pedidikan karakter di semua satuan pendidikan secara serentak mulai tahun ajaran 2011/2012.

Peningkatan mutu pendidikan terus dilakukan pemerintah seperti perbaikan kurikulum, penambahan jumlah guru dan pelatihan keprofesionalan guru. Namun, Soedijarto menyatakan bahwa pendidikan nasional salah satunya dihadapkan pada masalah pendidikan yang belum secara terencana dan sistematik diberdayakan untuk berfungsi dan mencapai tujuan pendidikan nasional secara optimal. Padahal menurut Pala (2011, p.31), pengembangan keterampilan sosialisasi dan integrasi pendidikan karakter adalah bagian penting dari kesuksesan akademik anak. Sehingga pendidikan nasional tidak hanya sekedar mengembangkan intelektualitas tetapi harus disertakan pembentukan watak dan perilaku yang baik, tangguh dan dapat beradaptasi dengan lingkungan sekaligus mencintai adat, budaya, dan menghargai serta menghormati negara maupun bangsanya sendiri yang diwujudkan dalam perilaku sehari-hari.

Namun demikian, sejauh ini pendidikan kita masih berorientasi pada pemenuhan nilai tertulis ketimbang aspek perilaku, sesuatu yang lebih krusial daripada itu (Mustofa, Kompas, 19 Mei 2014). Nilai tertulis atau lebih tepatnya aspek kognitif masih menjadi ukuran baku. Seharusnya pendidikan dirancang agar membawa siswa ke pengenalan nilai secara kognitif, penghayatan nilai secara afektif, dan akhirnya ke pengamalan nilai secara nyata, sehingga semua mata pelajaran yang dipelajari oleh siswa di sekolah harus bermuatan pendidikan karakter dengan harapan dapat membawa siswa menjadi manusia yang berkarakter. 
Pendidikan matematika dapat dipandang sebagai suatu keadaan atau sifat bahkan nilai yang bersinergis dengan pendidikan karakter. Pendidikan karakter dalam pembelajaran matematika di sekolah dapat menekankan kepada kemampuan hubungan antar manusia dan menghargai adanya perbedaan individu baik dalam kemampuan maupun pengalaman (Marsigit, 2013, p.13). Menurut Badan Standar Nasional Pendidikan (2006, p.140), mata pelajaran matematika bertujuan agar peserta didik memiliki kemampuan: (1) memahami konsep matematika; (2) menggunakan penalaran pada pola dan sifat; (3) memecahkan masalah; (4) mengomunikasikan gagasan; dan (5) memiliki sikap menghargai kegunaan matefmatika dalam kehidupan. Jelas bahwa matematika sekolah mempunyai peranan yang sangat penting bagi siswa agar mempunyai bekal pengetahuan dan terbentuk sikap serta pola pikirnya. Dengan demikian maka pembekalan karakter melalui pendidikan matematika sudah seharusnya diperhatikan dan diutamakan.

Penanaman pendidikan karakter dalam pembelajaran matematika berimplikasi pada fungsi guru sebagai fasilitator sebaik-baiknya agar siswa dapat mempelajari matematika secara optimal (Marsigit, 2013, p.13). Guru memiliki peran ganda di dalam pendidikan karakter. Pertama, guru menjadi model atau contoh perilaku yang sesuai dengan karakter yang dikembangkan. Kedua, guru mengontrol perilaku siswa agar sesuai dengan karakter yang diinginkan. Guru harus mampu mengajarkan matematika dengan mengintegrasikan nilai-nilai karakter, sebab setelah siswa memahami nilai-nilai karakter yang dikembangkan di sekolah, langkah selanjutnya adalah membiasakan siswa agar menerapkan nilai karakter tersebut. Namun demikian, Implementasi pendidikan karakter di lapangan masih memiliki berbagai kendala.

Kemendiknas (2010a, p.24) menyatakan bahwa pendidikan karakter secara terintegrasi di dalam pembelajaran adalah pengenalan nilainilai, fasilitasi diperolehnya kesadaran akan pentingnya nilai-nilai, dan penginternalisasian nilainilai ke dalam tingkah laku peserta didik seharihari melalui proses pembelajaran, baik yang berlangsung di dalam maupun di luar kelas pada semua mata pelajaran. Pada dasarnya kegiatan pembelajaran selain untuk menjadikan peserta didik menguasai kompetensi (materi) yang ditargetkan, juga dirancang untuk menjadikan peserta didik mengenal, menyadari/peduli, dan menginternalisasi nilai-nilai dan menjadikannya perilaku. Integrasi pendidikan karakter pada semua mata pelajaran dilakukan dalam rangka mengembangkan kegiatan intervensi pembelajaran yang dirancang untuk mencapai tujuan pembentukan karakter dengan penerapan pengalaman belajar terstruktur.

Menurut Kemendiknas (2010b, p.8) nilainilai yang dikembangkan dalam pendidikan karakter bersumber dari agama, pancasila, budaya dan tujuan pendidikan nasional. Berdasarkan empat nilai tersbut secara detail dalam Peraturan Walikota Yogyakarta Nomor 60 Tahun 2011 tentang pengembangan pendidikan karakter pada Satuan Pendidikan telah dirumuskan 18 nilai karakter yaitu (1) religius; (2) jujur; (3) toleransi; (4) disiplin; (5) mandiri; (6) cinta tanah air; (7) kerja keras; (8) kreatif; (9) rasa ingin tahu; (10) demokratis; (11) semangat kebangsaan; (12) menghargai prestasi; (13) bersahabat/ komunikatif; (14) cinta damai; (15) peduli sosial; (16) gemar membaca (17) tanggung jawab; dan (18) peduli lingkungan. Meskipun telah dirumuskan 18 nilai pembentuk karakter bangsa, namun menurut Sulistyowati (2012, p.77) tidak setiap mata pelajaran diberi integrasi semua butir nilai. Setiap mata pelajaran difokuskan pada beberapa nilai utama saja, meskipun tidak berarti bahwa nilai-nilai yang lain tidak diperkenankan diintegrasikan ke dalam mata pelajaran tertentu. Cara menentukan indikator nilai karakter yang dicapai pada setiap mata pelajaran dapat dilakukan dengan menyesuaikan karakteristik mata pelajaran itu sendiri. Selanjutnya integrasi pendidikan karakter di dalam proses pembelajaran dilaksanakan mulai dari tahap perencanaan, pelaksanaan, dan evaluasi pembelajaran pada semua mata pelajaran.

Namun, sejauh ini pendidikan karakter hanya sebatas konsep dan baru menyentuh pada tingkatan pengenalan norma atau nilai-nilai, dan belum pada tingkatan internalisasi dan tindakan nyata dalam kehidupan sehari-hari. Akbar (2011, pp.4-6) menyatakan bahwa ada beberapa masalah dalam praktik pendidikan dewasa ini yakni dunia pendidikan kurang mampu mengembangkan kepribadian peserta didik secara utuh sehingga kurang optimal menumbuhkan karakter baik. Salah satu masalah dalam praktik pendidikan dewasa ini adalah masalah penghadiran dan internalisasi nilai-nilai melalui berbagai mata pelajaran. Dalam praktiknya, banyak pengembang dan praktisi pendidikan yang kurang menyadari persoalan ini sehingga praktik pendidikan dan pembelajaran cenderung kurang berbasis nilai-nilai yang terkandung pada berbagai mata pelajaran yang disajikan. Selain itu 
proses belajar yang berupaya menggali aspek kreativitas dan berpusat pada siswa cenderung terpinggirkan karena lebih memfokuskan pada latihan-latihan soal (Driana, Kompas, 20 April 2013). Selain itu kendala mendasar dalam implementasi menurut Jumarudin, Gafur, \& Suardiman (2014, p.115) adalah masih banyak guru yang merasa bahwa pendidikan karakter sulit diterapkan dan membutuhkan alokasi waktu yang lebih banyak.

Berdasarkan permasalahan yang telah disebutkan, perlu adanya evaluasi yang difokuskan pada beberapa hal yang terkait dengan implementasi pendidikan karakter dalam pembelajaran matematika SMP di Kota Yogyakarta Penelitian ini bertujuan untuk mendeskripsikan (1) implementasi pendidikan karakter dalam pembelajaran matematika SMP di Kota Yogyakarta; (2) mendeskripsikan faktor pendukung dan penghambat implementasi pendidikan karakter dalam pembelajaran matematika SMP di Kota Yogyakarta

\section{METODE}

Jenis penelitian ini adalah penelitian evaluasi dengan pendekatan kuantitatif dan kualitatif. Menurut Stufflebeam (2002, p.280) "Evaluation is the process of delinieting, obtaining, reporting, and applying dscriptive and judgmental information about some object's merit, worth, probity, and significance in order to guide decision making, support accountability, disseminate effective practice, and increase understanding of the involved phenomena". Hal ini berarti evaluasi adalah proses menggambarkan, mendapatkan dan menyediakan informasi deskriptif serta mengambil keputusan tentang nilai dan manfaat dari tujuan yang dicapai, desain, implementasi dan dampak untuk memandu pengambilan keputusan, melayani kebutuhan untuk pertanggungjawaban dan meningkatkan pemahaman terhadap fenomena yang terlibat.

Model evaluasi yang digunakan dalam penelitian ini adalah model evaluasi kesenjangan (discrepancy model) yang dikembangkan oleh Malcon Provus. Menurut Steinmetz (2002, p.128), Discrepancy Evaluation Model (DEM) adalah perakitan ide dan prosedur yang timbul dari upaya menanggapi harapan masyarakat tentang apa yang akan terjadi secara konstruktif.

Penelitian ini dilaksanakan di Sekolah Menengah Pertama SMP) baik negeri maupun swasta di Kota Yogyakarta tahun ajaran 2015/
2016. Penelitian ini dilaksanakan pada bulan Januari-Mei 2016.

Populasi dalam penelitian ini adalah semua Sekolah Menengah Pertama (SMP) baik negeri maupun swasta di Kota Yogyakarta yaitu 66 SMP. Pengambilan sampel untuk sekolah dalam penelitian evaluasi ini menggunakan teknik stratified random sampling, teknik proportional random sampling dan teknik sampling purposive. Pengambilan sampel dengan teknik stratified random sampling dilakukan dengan membagi strata atau tingkatan menjadi tiga yaitu tinggi, sedang, dan rendah selanjutnya memilih sampel secara acak pada setiap strata dengan menggunakan teknik proportional random sampling. Sehingga diperoleh sampel sebanyak 22 SMP untuk pengumpulan data kuantitatif dan 6 SMP untuk pengumpulan data kualitatif. Pengambilan sampel sumber informasi untuk guru matematika dan siswa dilakukan dengan teknik sampling purposive. Pengambilan sampel dipilih secara selektif dimana peneliti memilih informan yang lebih mengetahui implementasi pendidikan dalam pembelajaran matematika SMP di Kota Yogyakarta secara mendalam sehingga dapat lebih dipercaya. Pertimbangan tersebut menjadi dasar peneliti untuk membatasi sampel sumber informasi penelitian pada guru yang mengajar matematika SMP karena guru yang mengajar matematika dianggap lebih mengetahui informasi tentang implementasi pendidikan karakter dalam pembelajaran matematika. Sampel dipilih guru matematika SMP kelas VII karena penanaman pendidikan karakter di kelas VII merupakan langkah awal guru dalam menanamkan pondasi nilai-nilai karakter kepada siswa.

Adapun variabel dalam penelitian ini yaitu (1) perencanaan; (2) pelaksanaan; dan (3) penilaian. Perencanaan pembelajaran meliputi kegiatan guru dalam menyusun perangkat pembelajaran, pengembangan silabus, dan pengembangan Rencana Pelaksanaan Pembelajaran (RPP) bermuatan nilai-nilai karakter. Pelaksanaan pembelajaran bermuatan pendidikan karakter meliputi kegiatan guru dalam melaksanakan pembelajaran sesuai dengan apa yang telah direncanakan yaitu kegiatan pendahuluan, inti dan penutup. Penilaian pembelajaran berkaitan dengan pendidikan karakter meliputi jenis tagihan, teknik penilaian, dan instrumen penilaian. Penilaian pembelajaran dilaksanakan dengan memperhatikan tiga komponen yaitu sikap, pengetahuan dan keterampilan. 
Adapun teknik pengumpulan data dalam penelitian ini adalah angket, wawancara, dokumentasi dan observasi. Angket merupakan teknik pengumpulan data yang dilakukan dengan cara memberikan seperangkat pertanyaan atau pernyataan kepada responden untuk dijawab. Angket yang digunakan dalam penelitian ini adalah angket tertutup. Penelitian ini menggunakan 2 macam angket yaitu angket guru dan angket siswa. Angket guru untuk mengungkap informasi tentang bagaimana kualitas perencanaan, pelaksanaan dan penilaian pembelajaran. Angket siswa untuk mengungkap informasi tentang bagaimana kualitas pelaksanaan dan penilaian pembelajaran.

Wawancara merupakan salah satu bentuk alat evaluasi jenis nontes yang dilakukan melalui percakapan dan tanya jawab, baik langsung maupun tidak langsung dengan peserta didik (Arifin, 2014, p.157). Teknik wawancara yang digunakan dalam penelitian ini adalah wawancara mendalam (dept interview). Sedangkan bentuk wawancara yang digunakan dalam penelitian ini adalah wawancara terstuktur dan tidak terstruktur. Peneliti melakukan wawancara dengan dipandu pedoman wawancara.

Dokumentasi adalah teknik pengumpulan data yang dilakukan dengan cara mengumpulkan data dan informasi melalui laporan dan dokumen sesuai tujuan penelitian. Penelitian ini menggunakan teknik pengumpulan data dengan cara memanfaatkan dokumen silabus dan RPP untuk kepentingan lembar penilaian. Lembar penilaian digunakan untuk mengungkap kualitas perencanaan pembelajaran dari silabus dan RPP yang telah dipersiapkan guru.

Observasi adalah suatu proses pengamatan dan pencatatan secara sistematis, logis, objektif, dan rasional mengenai berbagai fenomena, baik dalam situasi yang sebenarnya maupun dalam situasi buatan untuk mencapai tujuan tertentu (Arifin, 2014, p.153). Alat yang digunakan dalam melakukan observasi disebut lembar observasi. Teknik observasi yang digunakan dalam penelitian ini adalah non-participant observer yakni pengamatan dilakukan secara pasif tanpa terlibat langsung dalam kegiatan subjek penelitian.

Pembuktian validitas dalam penelitian ini menggunakan dua macam validitas yaitu validitas isi (content validity) dan validitas konstruk (construct validity). Validitas isi dalam penelitian ini dilakukan untuk membuktikan sejauh mana instrumen yang digunakan merepresentasikan konstruk yang sesuai dengan tujuan pengukuran meliputi angket, lembar penilaian, lembar observasi, serta pedoman wawancara. Validitas konstruk digunakan untuk membuktikan kevalidan instrumen angket. Untuk menentukan indeks validitas digunakan indeks validitas Aiken dengan rumus sebagai berikut:

$$
V=\frac{\sum_{i=1}^{n} s_{i}}{n(c-1)}
$$

\section{Keterangan:}

n: banyaknya ahli (validator)

c: banyaknya kategori yang dapat dipilih ahli. $\mathbf{s}_{\mathbf{i}}$ : Skor yang ditetapkan ahli (validator) ke i dikurangi skor kategori terendah

Menurut Retnawati (2015, p.43), jika indeks $V$ kurang dari 0,4 maka dikatakan validitasnya rendah, diantara 0,4-0,8 dikatakan validitasnya sedang, dan jika lebih dari 0,8 maka dikatakan validitasnya tinggi. Berdasarkan penilaian ahli diperoleh indeks validitas aiken sebesar 0,98 untuk insrumen angket guru, 0,83 untuk instrumen angket siswa, 1 untuk lembar penilaian silabus dan RPP, pedoman wawancara, dan lembar observasi. Jadi dapat dikatakan bahwa validitas butir semua instrumen valid. Selanjutnya untuk membuktikan validitas isi instrumen digunakan pengkategorian yang dikemukakan Azwar (2010, p.163) dalam Tabel 1.

Tabel 1. Kriteria Skor Kuantitatif

\begin{tabular}{cc}
\hline Interval Skor & Kategori \\
\hline $\boldsymbol{x}_{\boldsymbol{i}}+\mathbf{1}, \mathbf{5} \boldsymbol{S} \boldsymbol{b}_{\boldsymbol{i}}<\boldsymbol{x}$ & Sangat Tinggi \\
$\boldsymbol{x}_{\boldsymbol{i}}+\mathbf{0}, \mathbf{5} \boldsymbol{S} \boldsymbol{b}_{\boldsymbol{i}}<\boldsymbol{x} \leq \boldsymbol{x}_{\boldsymbol{i}}+\mathbf{1}, \mathbf{5} \boldsymbol{S} \boldsymbol{b}_{\boldsymbol{i}}$ & Tinggi \\
$\boldsymbol{x}_{\boldsymbol{i}}-\mathbf{0}, \mathbf{5} \boldsymbol{S} \boldsymbol{b}_{\boldsymbol{i}}<\boldsymbol{x} \leq \boldsymbol{x}_{\boldsymbol{i}}+\mathbf{0}, \mathbf{5} \boldsymbol{S} \boldsymbol{b}_{\boldsymbol{i}}$ & Cukup \\
$\boldsymbol{x}_{\boldsymbol{i}}-\mathbf{1}, \mathbf{5} \boldsymbol{S} \boldsymbol{b}_{\boldsymbol{i}}<\boldsymbol{x} \leq \boldsymbol{x}_{\boldsymbol{i}}+\mathbf{0}, \mathbf{5} \boldsymbol{S} \boldsymbol{b}_{\boldsymbol{i}}$ & Rendah \\
$\boldsymbol{x} \leq \boldsymbol{x}_{\boldsymbol{i}}-\mathbf{1}, \mathbf{5 S} \boldsymbol{b}_{\boldsymbol{i}}$ & Sangat Rendah \\
\hline
\end{tabular}

Keterangan:

$\mathrm{x}$ : skor aktual.

$\mathrm{x}_{\mathrm{i}}$ : rerata skor ideal yaitu $\frac{1}{2}$ (skor maksimum + skor minimum)

$\mathrm{Sb}_{\mathrm{i}}$ : simpangan baku ideal yaitu $\frac{1}{6}$ (skor maksimum - skor minimum).

Skor maksimum: banyak butir x skor tertinggi.

Skor minimum: banyak butir x skor terendah.

Instrumen dianggap valid apabila penilaian ahli memenuhi klasifikasi secara kualitatif minimal tinggi. Berdasarkan hasil validasi dari ahli, dapat disimpulkan bahwa instrumen angket, lembar penilaian, lembar observasi, serta pedoman wawancara dikatakan valid. Selanjutnya berdasarkan validitas konstruk eksploratori 


\section{Jurnal Riset Pendidikan Matematika, 4 (2), 2017 - 158}

Indah Pertiwi, M. Marsigit

disimpulkan bahwa angket guru dan siswa adalah valid.

Estimasi reliabilitas yang digunakan dalam penelitian ini adalah dengan menggunakan koefisien Alpha Cronbach untuk angket, sedangkan reliabilitas untuk lembar penilaian silabus dan RPP, lembar observasi dan pedoman wawancara menggunakan interrater. Menurut Gable (1986, p.147) instrumen mempunyai indeks keandalan yang baik jika koefisien reliabilitasnya minimum 0,70 . Dengan bantuan SPSS 20.0 diperoleh koefisien reliabilitas sebesar 0,932 sehingga lembar kuesioner penelitian reliabel atau memiliki konsistensi pengukuran.

\section{Teknik Analisis Data}

Analisis data angket guru dan siswa dilaksanakan dengan menggunakan analisis deskriptif kuantitatif. Analisis deskriptif kuantitatif digunakan untuk mendeskripsikan dan memaknai tiap-tiap komponen data evaluasi kemudian dibandingkan dengan acuan kriteria yang telah ditentukan berdasarkan lima kriteria yang diadaptasi dari Peraturan Menteri Negara Pendayagunaan Aparatur Negara dan Reformasi Birokrasi Nomor 16 Tahun 2009 tentang jabatan guru dan angka kreditnya disajikan Tabel 2.

Tabel 2. Kategori Keterlaksanaan Program Implementasi Pendidikan Karakter

\begin{tabular}{cc}
\hline Interval & Kategori \\
\hline$X>90$ & Sangat Baik \\
$75<X \leq 90$ & Baik \\
$60<X \leq 75$ & Cukup \\
$50<X \leq 60$ & Kurang \\
$X \leq 50$ & Sangat Kurang \\
\hline
\end{tabular}

Keterangan:

$X$ : skor yang dicapai

Menentukan nilai responden berdasarkan rumus berikut.

$X=\frac{\text { skor yang diperoleh responden }}{\text { skor tertinggi ideal }} \times 100$

Tahapan kerja analisis data kualitatif dapat dilihat pada Gambar 1.

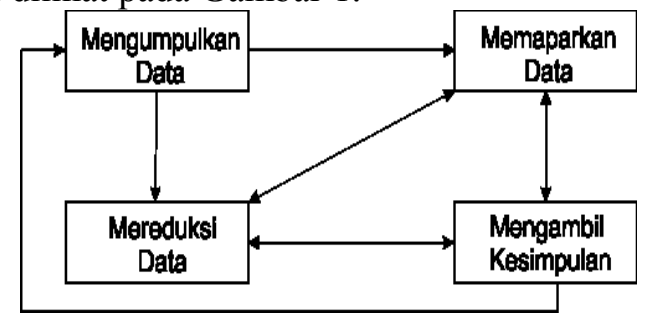

Gambar 1. Komponen-komponen Analisis Data Model Interaktif

\section{HASIL DAN PEMBAHASAN}

Implementasi pendidikan karakter dalam pembelajaran matematika meliputi perencanaan, pelaksanaan dan penilaian. Perencanaan berkaitan dengan implementasi pendidikan karakter meliputi kegiatan guru dalam menyusun perangkat pembelajaran, pengembangan silabus, dan pengembangan Rencana Pelaksanaan Pembelajaran (RPP) bermuatan nilai-nilai karakter. Pendidikan karakter dalam perencanaan pembelajaran matematika terdiri atas dua indikator yaitu: (1) membuat silabus bermuatan nilai-nilai karakter sebagai acuan dalam pengembangan RPP; dan (2) membuat RPP bermuatan nilainilai karakter sebagai pedoman pembelajaran yang memenuhi standar proses.

Pelaksanaan berkaitan dengan implementtasi pendidikan karakter meliputi kegiatan guru dalam melaksanakan pembelajaran sesuai dengan apa yang telah direncanakan. Kegiatan tersebut seperti melaksanakan kegiatan pendahuluan, inti dan penutup. Pendidikan karakter dalam pelaksanaan pembelajaran matematika terdiri atas tiga indikator yaitu (1) melaksanakan kegiatan pembuka sesuai dengan RPP yang bermuatan nilai-nilai karakter; (2) melaksanakan kegiatan inti sesuai dengan RPP yang bermuatan nilai-nilai karakter; (3) melaksanakan kegiatan penutup sesuai dengan RPP yang bermuatan nilai-nilai karakter.

Penilaian pembelajaran berkaitan dengan pendidikan karakter meliputi jenis tagihan, teknik penilaian, dan instrumen penilaian. Penilaian pembelajaran dilaksanakan dengan memperhatikan tiga komponen yaitu sikap, pengetahuan, dan keterampilan. Pendidikan karakter dalam penilaian pembelajaran matematika terdiri atas tiga indikator yaitu (1) melakukan penilaian hasil pembelajaran sehingga tingkat kompetensi peserta didik dapat diketahui; (2) menggunakan beragam teknik penilaian hasil pembelajaran baik tes maupun nontes; (3) melakukan penilaian proses/hasil pendidikan karakter.

Secara keseluruhan hasil analisis implementasi pendidikan karakter dalam pembelajaran matematika SMP di Kota Yogyakarta berdasarkan angket guru dan angket siswa termasuk dalam kategori cukup dengan perolehan skor sebesar 62. Analisis implementasi pendidikan karakter dalam pembelajaran matematika SMP di Kota Yogyakarta disajikan dalam Tabel 3. 
Tabel 3. Hasil Analisis Implementasi Pendidikan Karakter dalam Pembelajaran Matematika SMP di Kota Yogyakarta

\begin{tabular}{ccccc}
\hline No & Sekolah & Guru & Siswa & Kategori \\
\hline 1 & SMP Negeri & 61 & 62 & Cukup \\
2 & SMP Swasta & 62 & 61 & Cukup \\
& Rata-rata & 62 & 62 & Cukup \\
\hline
\end{tabular}

\section{Perencanaan}

Internalisasi nilai-nilai karakter dapat dimulai dengan mengidentifikasi nilai-nilai yang akan diinternalisasi, kemudian menentukan pendekatan yang akan digunakan untuk menginternalisasi nilai tersebut pada diri siswa, selanjutnya menyusun perencanaan program jangka pendek, menengah, dan panjang untuk menginternalisasi dan mengaktualisasi nilai-nilai tersebut (Widyaningsih, Zamroni, \& Zuchdi, 2014, p.195). Menurut Sanjaya (2012, p.34), salah satu manfaat perencanaan adalah perencanaan akan dapat membuat pembelajaran berlangsung secara sistematis artinya pembelajaran akan berlangsung secara terarah dan terorganisir. Sehingga perencanaan pembelajaran atau persiapan pembelajaran menjadi sangat penting karena menentukan arah dan tujuan dari kegiatan pembelajaran. Selain itu kegiatan persiapan juga dapat digunakan sebagai personal resource yang dapat memberikan kontribusi pada kurikulum yang digunakan guru. Setiap guru memiliki kewajiban untuk menyusun perencanaan pembelajaran yang akan digunakan dalam proses belajar mengajar di kelas agar kegiatan pembelajaran lebih terarah sehingga tujuan yang diharapkan akan tercapai.

Data evaluasi pendidikan karakter dalam perencanaan pembelajaran matematika diperoleh melalui angket guru dilanjutkan dengan penilaian terhadap silabus dan RPP. Hasil evaluasi angket guru tentang pendidikan karakter dalam perencanaan pembelajaran matematika SMP di Kota Yogyakarta secara keseluruhan termasuk dalam kategori cukup dengan skor rata-rata sebesar 66. Hasil perolehan nilai pendidikan karakter dalam perencanaan pembelajaran matematika SMP di Kota Yogyakarta disajikan dalam Tabel 4.

Tabel 4. Hasil Analisis Pendidikan Karakter dalam Perencanaan Pembelajaran Matematika SMP di Kota Yogyakarta

\begin{tabular}{cccc}
\hline No & Sekolah & Hasil & Kategori \\
1. & SMP Negeri & 63 & Cukup \\
2. & SMP Swasta & 68 & Cukup \\
& Rata-rata & 66 & Cukup \\
\hline
\end{tabular}

Setelah dilakukan pengambilan data angket guru selanjutnya dilakukan crosscheck terhadap pendidikan karakter dalam perencana-an pembelajaran matematika. Peneliti melaku-kan penilaian terhadap silabus dan RPP yang telah dibuat guru sebagai crosscheck hasil data kuantitatif yang diperoleh dari angket guru. Hasil analisis lembar penilaian silabus dan RPP menunjukkan bahwa perencanaan pembelajaran matematika bermuatan pendidikan karakter baik dalam lembar penilaian silabus maupun RPP termasuk dalam kategori cukup. Artinya guru telah menyusun silabus dan RPP uang bermuatan nilai-nilai karakter namun belum terintegrasi dalam materi pelajaran matematika. Permasalahannya adalah guru mengalami kesulitan dalam mengidentifikasi dan memetakan nilai karakter yang sesuai dengan materi. Hal tersebut ditunjukkan dari ketidakmunculan beberapa deskriptor sehingga terdapat kesenjangan antara standar dan fakta.

Selain itu, berdasarkan hasil wawancara, guru mengatakan bahwa salah satu kendala yang dialami adalah penyusunan rencana implementasi pendidikan karakter cukup menguras banyak waktu. Padahal guru memiliki berbagai tuntutan seperti menyelesaikan materi dan tugas administrasi. Sehingga hendaknya seorang guru mampu menyisihkan waktu untuk menyusun rencana pembelajaran. Pengetahuan guru tentang penyusunan rancana pembelajaran, penggunaan rencana pembelajaran dan pengalokasian waktu yang tepat agar dapat menyusun rencana pembelajaran merupakan hal yang harus diperhatikan seorang guru.

\section{Pelaksanaan}

Pendidikan karakter dalam pelaksanaan pembelajaran matematika merupakan suatu proses implementasi pendidikan karakter dalam pembelajaran matematika yang telah disusun dalam RPP meliputi kegiatan pendahuluan, kegiatan inti dan kegiatan penutup. Kegiatan pendahuluan memuat kegiatan-kegiatan yang dapat menarik perhatian siswa sehingga dapat menjembatani pencapaian tujuan pembelajaran. Kegiatan inti dilakukan dengan memadukan model-model pembelajaran yang sesuai dengan materi dan nilai-nilai karakter, adanya penggunaan media pembelajaran pendukung KBM serta kegiatan penilaian yang dilakukan guru selama pembelajaran berlangsung. Sedangkan kegiatan penutup adalah kegiatan yang dapat dilakukan guru untuk mengetahui sejauhmana kegiatan pembelajaran telah terlaksana. 


\section{Jurnal Riset Pendidikan Matematika, 4 (2), 2017 - 160}

Indah Pertiwi, M. Marsigit

Guru sebagai paktisi pendidikan telah merencanakan penerapan pendidikan karakter dengan memasukkan nilai-nilai karakter pada RPP. Namun, menurut Jumarudin, Gafur, \& Suardiman (2014, p115) rencana pembelajaran yang telah disusun seringkali tidak terlaksana sebagaimana mestinya.

Data kuantitatif evaluasi pendidikan karakter dalam pelaksanaan pembelajaran matematika di Kota Yogyakarta diperoleh melalui angket guru dan angket siswa. Hasil evaluasi angket guru dan angket siswa tentang pendidikan karakter dalam pelaksanaan pembelajaran matematika SMP di Kota Yogyakarta secara keseluruhan termasuk dalam kategori cukup dengan skor rata-rata 66 dari skor maksimal 100. Artinya guru masih mengalami kesulitan dalam melaksanakan implementasi pendidikan karakter dalam pembelajaran matematika. Hasil angket guru juga didukung dengan angket siswa. Hasil analisis pendidikan karakter dalam pelaksanaan pembelajaran matematika SMP di Kota Yogyakarta disajikan dalam Tabel 5.

Tabel 5. Hasil Analisis Pendidikan Karakter dalam Pelaksanaan Pembelajaran Matematika SMP di Kota Yogyakarta

\begin{tabular}{ccccc}
\hline No & Sekolah & Guru & Siswa & Kategori \\
\hline $\mathbf{1}$ & SMP Negeri & 65 & 66 & Cukup \\
$\mathbf{2}$ & SMP Swasta & 66 & 67 & Cukup \\
& Rata-rata & 66 & 66 & Cukup \\
\hline
\end{tabular}

Hasil evaluasi angket guru dan angket siswa di crosscheck dengan melakukan observasi kelas karena implementasi pendidikan karakter juga dilaksanakan dalam kegiatan belajar mengajar, sesuai dengan mata pelajaran masingmasing, termasuk pelajaran matematika. Berdasarkan hasil observasi dapat diketahui bahwa fakta yang ada di lapangan bertolak-belakang dengan salah satu prinsip pengembangan pendidikan budaya dan karakter bangsa yaitu proses pendidikan dilakukan peserta didik secara aktif dan menyenangkan. Konsep belajar aktif menurut Kemendiknas (2010b, p.iv) adalah sesuai dengan prinsip pengembangan nilai harus dilakukan secara aktif oleh peserta didik (dirinya subjek yang akan menerima, menjadikan nilai sebagai miliknya dan menjadikan nilai-nilai yang sudah dipelajarinya sebagai dasar dalam setiap tindakan) maka posisi peserta didik sebagai subjek yang aktif dalam belajar adalah prinsip utama belajar aktif. Kamaruddin (2012, p. 226) menambahkan bahwa pembelajaran aktif berpusat pada siswa berarti siswa berpartisipasi dalam proses belajar sebanyak mungkin.
Berdasarkan hasil observasi pembelajaran menunjukkan bahwa banyak guru belum menerapkan pendekatan belajar aktif dan menyenangkan. Hanya beberapa guru yang mempersiapkan dan memberikan pembelajaran aktif dan menyenangkan dalam menjelaskan materi pelajaran sehingga proses belajar mengajar tidak monoton dan tidak membosankan bagi siswa. Selanjutnya tidak terlihat guru melakukan penekanan pada nlai-nilai tertentu. Pendidikan karakter belum sepenuhnya terintegrasi melalui pembelajaran matematika sebab sebagian besar guru masih terfokus pada penyampaian materi. Selain itu ditemukan pengamatan lain bahwa hampir semua proses pembelajaran matematika di kelas tidak dilakukan sebagaimana yang tersusun dalam RPP bahkan beberapa guru tidak berpedoman pada RPP. Padahal di dalam RPP secara eksplisit telah dicantumkan tahapan kegiatan dan nilai-nilai karakter yang akan ditanamkan kepada siswa. Menurut informasi yang diperoleh dari guru melalui wawancara bahwa pembelajaran dilakukan sesuai kebutuhan sehingga sering tidak sesuai dengan RPP. Biasanya materi pelajaran dipadatkan di awal untuk mengantisipasi hari libur dan jika masih ada hari belajar efektif di akhir semester akan digunakan untuk mengulang atau pendalaman materi seperti mengerjakan latihan soal.

Proses pembelajaran yang dilakukan idealnya condong ke arah pembentukan karakter siswa. Namun berdasarkan pengamatan yang telah dijelaskan bahwa pembelajaran lebih berorientasi pada penyampaian materi. Kemendiknas (2010a, p.24) menjelaskan bahwa terdapat dua jenis pengalaman belajar (learning experiences) yang dibangun yaitu melalui intervensi dan habituasi. Intervensi adalah suasana interaksi belajar dan pembelajaran yang sengaja dirancang untuk mencapai tujuan pembentukan karakter dengan menerapkan kegiatan yang terstruktur. Oleh karena itu, guru harus berperan aktif dalam proses pembelajaran guna menekan nilai karakter tertentu. Dengan kata lain, pendidikan nilai karakter tidak dapat mengalir apa adanya namun perlu terprogram dengan jelas dan dilaksanakan sesuai program yang telah direncanakan.

Intervensi nilai karakter dalam pembelajaran tidak hanya dengan memberikan contohcontoh perilaku baik namun diperlukan metode yang komprehensif meliputi dimensi pengolahan diri yaitu olah pikir, olah hati, dan olah raga sesuai dengan 'components of good character' yang dicetuskan oleh Lickona (2013, p.241). 
Berdasarkan teori tersebut, maka guru perlu berupaya untuk memberikan pemahaman kepada siswa tentang nilai yang diajarkan, mengapa nilai tersebut penting dimiliki, atau apakah sikap yang dimiliki siswa sudah benar atau belum. Setelah itu memberikan penguatan dalam aspek emosinya untuk merasakan nilai-nilai moral yang selanjutnya akan direpresentasikan melalui tindakan. Namun kenyataan di lapangan proses intervensi ini belum mendalam. Guru baru sebatas mengenalkan nilai-nilai tertentu belum mengarah pada memberikan pemahaman akan suatu nilai.

Kemudian proses selanjutnya adalah habituasi. Habituasi berkaitan dengan pembiasaan diri. Pada konteks pendidikan karakter, habituasi meliputi situasi dan kondisi dan pengutaan yang diciptakan agar memungkinkan siswa membiasakan diri berperilaku sesuai nilai karakter yang telah diinternalisasikan dan dipersonalisasikan proses intervensi (Kemendiknas, 2010a, p.33). Pada proses habituasi ini, sebagian besar guru belum melakukannya.

Guru sebagai fasilitator dalam kegiatan belajar mengajar di kelas memiliki pengalaman sosial yang lebih luas untuk membentuk karakter siswa, sebab karakter dianggap terbentuk tidak secara otomatis tetapi dikembangkan melalui pengajaran (Nucci \& Narvaes , 2008, p.96). Guru bertugas menuntun siswa agar aktif tanpa harus mengatakan bahwa siswa harus aktif, namun guru merencakaan kegiatan pembelajaran yang dapat menimbulkan siswa aktif merumuskan pertanyaan, mencari informasi, mengumpulkan informasi dari sumber, mengolah informasi yang sudah dimiliki, merekonstruksi data, menyajikan hasil sehingga dapat menumbuhkan nilai-nilai karakter pada diri siswa melalui kegiatan belajar di kelas. Siswa akan secara aktif terlibat dalam pelajaran mengeksplorasi dan menemukan poin-poin penting (Cline, Burelle, \& Zullo, 2012, p.212). Berdasarkan data observasi dapat diketahui bahwa interaksi antara guru dan siswa sudah terjalan dengan baik. Terjadi komunikasi yang hangat diantara guru dan siswa. Guru memberikan kesempatan kepada siswa untuk mengutarakan pendapatnya melalui metode tanya jawab. Namun masih dijumpai pembelajaran satu arah yang dilakukan oleh guru sehingga siswa cenderung pasif. Selain itu masih dijumpai metode tanya jawab yang tidak terstruktur dengan baik.

\section{Penilaian}

Majid (2012, pp.186-187) menyatakan bahwa penilaian otentik adalah proses pengumpulan informasi oleh guru tentang perkembangan dan pencapaian pembelajaran yang dilakukan anak didik melalui berbagai teknik yang mampu mengungkapkan, membuktikan atau menunjukkan secara tepat bahwa tujuan pembelajaran dan kemampuan (kompetensi) telah benar-benar dikuasai dan dicapai. Penilaian pembelajaran matematika tidak hanya diarahkan pada hasil akhir saja, akan tetapi juga penilaian selama proses pembelajaran, sehingga penilaian untuk kompetensi sikap, pengetahuan, dan ketrampilan dapat tercapai secara menyeluruh. Penilaian tidak hanya dilakukan oleh guru namun juga penilaian dari teman sejawat maupun penilaian diri sendiri.

Data kuantitatif evaluasi pendidikan karakter dalam penilaian pembelajaran matematika di Kota Yogyakarta diperoleh melalui angket guru dan angket siswa. Hasil evaluasi pendidikan karakter dalam penilaian pembelajaran matematika SMP di Kota Yogyakarta secara keseluruhan termasuk dalam kategori kurang dengan skor rata-rata berdasarkan angket guru sebesar 54 dan berdasarkan angket siswa sebesar 57 dari skor maksimal 100. Artinya pendidikan karakter dalam penilaian pembelajaran matematika belum berjalan dengan baik karena guru masih mengalami kesulitan dalam melakukan penilaian pendidikan karakter yang tampak pada siswa. Hasil analisis pendidikan karakter dalam penilaian pembelajaran matematika SMP di Kota Yogyakarta disajikan dalam Tabel 6.

Tabel 6. Hasil Analisis Pendidikan Karakter dalam Penilaian Pembelajaran Matematika SMP di Kota Yogyakarta

\begin{tabular}{ccccc}
\hline No & Sekolah & Guru & Siswa & Kategori \\
\hline 1 & SMP Negeri & 56 & 59 & Kurang \\
2 & SMP Swasta & 52 & 55 & Kurang \\
& Rata-rata & 54 & 57 & Kurang \\
\hline
\end{tabular}

Selanjutnya peneliti melakukan crosschek terhadap pendidikan karakter dalam penilaian pembelajaran matematika dengan melakukan observasi penilaian pendidikan karakter yang dilaksanakan dalam kegiatan belajar mengajar maupun pada saat ulangan. Berdasarkan hasil observasi kelas, pada aspek kognitif dan psikomotorik sudah terlaksana dengan baik, sedangkan penilaian pada aspek afektif, hasil pengamatan menunjukkan bahwa penilaian nilai-nilai karakter dalam proses belajar mengajar belum 
terlihat. Hal tersebut dikarenakan penilaian sikap yang berkaitan dengan nilai karakter masih dirasa sulit bagi sebagian besar guru sehingga mayoritas sekolah tidak memiliki dokumentasi perkembangan nilai karakter yang ditunjukkan siswa di sekolah. Padahal mayoritas guru mengaku telah melakukan pengamatan terhadap nilai karakter yang nampak pada siswa, namun guru masih masih mengalami kendala dalam pencatatan hasil pengamatan terhadap nilai karakter tersebut. Tidak ada satupun sekolah yang telah membuat penilaian sikap tersebut. Kondisi ini dapat diketahui bahwa pendidikan karakter sebagai sebuah program sangat kurang dalam hal penilaian. Sekolah tidak memiliki patokan yang jelas tentang kriteria penilaian sikap siswa. Cara lisan yang biasa dilakukan guru tidak menjadi masalah bagi guru karena ketika permasalahan muncul guru langsung memberikan tindak lanjut agar siswa dapat langsung memperbaikinya. Padahal penilaian lisan ini sangat lemah untuk dijadikan dasar pertimbangan dalam menentukan kesimpulan profil siswa. sebab, ingatan manusia sifatnya sangat terbatas sehingga tidak semua dapat diingat tepat dengan apa yang sebelumnya pernah diamati. Selain itu, tidak ada bukti fisik yang jelas sehingga mengurangi nilai objektivitas dan akuntabilitas.

Penilaian sikap digunakan untuk memberikan feedback langsung kepada siswa dan diperlukan untuk assesment pribadi guru. Kesimpulan yang lugas seperti Belum Terlihat (BT), Mulai Terlihat (MT), Mulai Berkembang (MB), dan Membudaya (MK) akan memberkan gambaran bagi seorang guru tentang karakter apa saja yang sudah bak atau karakter mana yang masih perlu diperbaiki.

\section{Faktor Pendukung}

Faktor pendukung yang dialami oleh guru matematika dalam mengimplementasikan pendidikan karakter dalam pembelajaran matematika yaitu faktor pendukung perencanaan meliputi: (1) visi dan misi yang dimiliki sekolah, dan (2) adanya peraturan dan tata tertib yang telah diatur sekolah. Faktor pendukung pelaksanaan meliputi: (1) dukungan dan kerja sama yang baik antara lingkungan sekolah maupun warga sekolah, (2) kondisi siswa yang telah memiliki dasar karakter baik, dan (3) contoh perilaku positif guru sebagai teladan. Peraturan dan tata tertib di setiap sekolah berbeda-beda begitupun dengan sanksi yang diberikan.

\section{Faktor Penghambat}

Faktor penghambat yang dialami oleh guru matematika dalam mengimplementasikan pendidikan karakter dalam pembelajaran matematika yaitu: faktor penghambat perencanaan meliputi: (1) guru belum memiliki pemahaman yang memadai tentang konsep pendidikan karakter terutama implementasi dalam pembelajaran matematika, dan (2) guru masih mengalami kesulitan dalam mengidentifikasi nilainilai karakter dari kompetensi dasar pada mata pelajaran matematika. Faktor penghambat pelaksanaan meliputi: (1) guru belum dapat mengimplementasikan pendidikan karakter yang terintegrasi dalam pembelajaran matematika dengan baik, dan (5) sarana dan prasarana yang belum lengkap. Faktor penghambat penilaian yaitu dokumentasi penilaian sikap siswa masih lemah. Guru telah membuat perencanaan pembelajaran berupa silabus dan RPP, RPP yang dibuat beberapa guru pun telah mencantumkan nilai-nilai karakter yang dapat dikembangkan namun tidak jelas dari mana nilai-nilai karakter tersebut dikembangkan. Selanjutnya tidak adanya dokumentasi penilaian sikap karena guru mengalami kendala dalam melakukan penilaian dengan aspek yang banyak dan jumlah peserta didik yang banyak pula sehingga penilaian autentik tidak dapat dilakukan secara maksimal.

Program pendidikan karakter merupakan suatu pembaharuan yang dilakukan dalam bidang pendidikan. Namun demikian, pendidikan karakter bukan hanya sekedar trend baru dalam dunia pendidikan. Implementasi pendidikan karakter merupakan wujud nyata dari restorasi pendidikan yaitu mengembalikan hakikatnya untuk membangun manusia seutuhnya, yakni pendidikan yang membentuk manusia unggul dalam pengetahuan dan akhlak yang baik. Sekolah menjadi lingkungan yang berhadapan langsung dengan anak dan guru merupakan seseorang yang dekat dengan siswa sehingga mampu memberikan dampak positif bagi perkembangan karakter siswa. Oleh karena itu, sekolah diharapkan untuk memiliki komitmen dan integritas untuk membangun karakter anak bangsa melalui proses pendidikan salah satunya integrasi dalam mata pelajaran.

\section{SIMPULAN}

Berdasarkan hasil analisis dan pembahasan, implementasi pendidikan karakter dalam pembelajaran matematika SMP di Kota Yogyakarta dapat disimpulkan bahwa implementasi 
pendidikan karakter dalam pembelajaran matematika SMP di Kota Yogyakarta termasuk dalam kategori cukup dengan perolehan skor rata-rata sebesar 62 dari skor maksimal 100. Pendidikan karakter dalam perencanaan pembelajaran matematika SMP di Kota Yogyakarta termasuk dalam kategori cukup. Sebagian besar guru telah membuat silabus dan RPP namun masih mengalami kesulitan terutama dalam mengidentifikasi nilai-nilai karakter dari kompetensi dasar. Pendidikan karakter dalam pelaksanaan pembelajaran matematika SMP di Kota Yogyakarta termasuk dalam kategori cukup. Sebagian besar guru masih terpaku pada gaya belajar konvensional yang kurang memfasilitasi siswa untuk aktif sehingga implementasi pendidikan karakter belum berjalan optimal. Pendidikan karakter dalam penilaian pembelajaran matematika SMP di Kota Yogyakarta termasuk dalam kategori kurang. Banyak guru yang belum melakukan penilaian sikap sehingga dokumentasi penilaian sikap tidak ada.

Faktor pendukung perencanaan antara lain: (1) visi dan misi yang dimiliki sekolah, dan (2) adanya peraturan dan tata tertib yang telah diatur sekolah. Faktor pendukung pelaksanaan antara lain: (1) dukungan dan kerja sama yang baik antara lingkungan sekolah maupun warga sekolah, (2) kondisi siswa yang telah memiliki dasar karakter baik, dan (3) contoh perilaku positif guru sebagai teladan.

Faktor penghambat perencanaan antara lain: (1) guru belum memiliki pemahaman yang memadai tentang konsep pendidikan karakter terutama implementasi dalam pembelajaran matematika, dan (2) guru masih mengalami kesulitan dalam mengidentifikasi nilai-nilai karakter dari kompetensi dasar pada mata pelajaran matematika. Faktor penghambat pelaksanaan antara lain: (1) guru belum dapat mengimplementasikan pendidikan karakter yang terintegrasi dalam pembelajaran matematika dengan baik, dan (5) sarana dan prasarana yang belum lengkap. Faktor penghambat penilaian yaitu dokumentasi penilaian sikap siswa masih lemah.

Dinas pendidikan agar memfasilitasi pelatihan implementasi pendidikan karakter dalam pembelajaran matematika dengan narasumber yang berkompeten dibidangnya dan mempunyai pengetahuan yang luas tentang pendidikan karakter sehingga dapat membantu guru dalam merencanakan, melaksanakan dan melakukan penilaian pembelajaran matematika bermuatan pendidikan karakter. Perlu adanya monitoring dan evaluasi secara berkelanjutan yang dilakukan untuk mengendalikan dan mengontrol kualitas dan proses implementasi pendidikan karakter dalam pembelajaran matematika SMP di Kota Yogyakarta. Perlu adanya instrumen yang valid agar dapat digunakan guru untuk menilai atau mengevaluasi nilai karakter siswa pada pembelajaran matematika. Dinas Pendidikan dapat menentukan satu sekolah di setiap wilayah untuk menjadi sekolah best practice atau sekolah percontohan implementasi pendidikan karakter. Sekolah tersebut berperan sebagai pemberi pengalaman dan pengetahuan kepada sekolah lain. Cara ini juga bisa menyiasati keterbatasan Dinas Pendidikan dalam menjangkau semua sekolah secara langsung.

Sekolah hendaknya melakukan evaluasi intern berkaitan dengan implementasi pendidikan karakter pada semua mata pelajaran termasuk matematika baik dalam perencanaan, pelaksanaan maupun penilaian. Sekolah hendaknya mengoptimalan ketersediaan sarana dan prasarana yang mendukung implementasi pendidikan karakter dalam pembelajaran matematika seperti buku pegangan guru yang bermuatan nilai-nilai karakter, media pembelajaran, dan alat peraga matematika sehingga implementasi pendidikan karakter dalam pembelajaran matematika dapat berjalan optimal. Sekolah hendaknya melakukan pendampingan terhadap guruguru dalam mengimplementasikan pendidikan karakter dalam pembelajaran sehingga dapat berjalan optimal.

Terkait dengan pengintegrasian dalam mata pelajaran matematika, hendaknya guru merancang silabus dan RPP bermuatan nilai-nilai karakter dalam pembelajaran matematika dan hendaknya mengoptimalkan dengan mengembangkan metode yang lebih menarik dan inovatif dalam menanamkan pendidikan karakter dalam pembelajaran matematika. Guru hendaknya malakukan tindakan proaktif dalam menambah pengetahuan sebagai bentuk professionalisme karena informasi dapat diperoleh dari manapun untuk memperkaya pengetahuan dan keterampilan seperti berdiskusi mengenai pendidikan karakter dalam MGMP/KKG.

\section{DAFTAR PUSTAKA.}

Akbar, S. (Juni 2011). Revitalisasi pendidikan karakter di sekolah dasar. Makalah disajikan dalam Pidato Pengukuhan Guru Besar, di Universitas Malang. 
Arifin, Z. (2014). Evaluasi pembelajaran prinsip, teknik, prosedur. Bandung: PT Remaja Rosdakarya.

Arthur, J. (2003). Education with character the moral economy of schooling. New York: Routledge Falmer.

Azwar, S. (2015). Tes prestasi fungsi pengembangan pengukuran prestasi belajar. Yogyakarta: Pustaka Pelajar.

Badan Standar Nasional Pendidikan. (2006). Standar isi untuk satuan pendidikan dasar dan menengah. Jakarta: BSNP.

Cline, K., Burelle, J. M., \& Zullo, H. (2012). A question library classroom. Mathematics Teacher, Vol. 100, No.3.

Driana, E. (20 April 2013). Masih perlukan ujian nasional. Diambil pada tanggal 4 Oktober 2016, dari http://edukasi. kompas.com/read/2013/04/20/10084413/ Masih.Perlukah.Ujian.Nasional

Gable, R. K. (1986). Instrumen development in the affective domain. New York: Springer Sciences+Business Media.

Jumarudin, J., Gafur, A., \& Suardiman, S. (2014). Pengembangan model pembelajaran humanis religius dalam pendidikan karakter di sekolah dasar. Jurnal Pembangunan Pendidikan: Fondasi dan Aplikasi, 2(2). doi:http://dx.doi.org/10.21831/jppfa.v2i2. 2623

Kamaruddin S. A. (2012). Character education and students social behavior. Journal of Education and Learning. Vol.6 (4) pp. 223-230.

Kemendiknas. (2010a). Desain induk pendidikan karakter. Jakarta: Kemdiknas.

Kemendiknas. (2010b). Pengembangan pendidikan budaya dan karakter bangsa. Jakarta: Badan Penelitian dan Pengembangan Pusat Kurikulum.

Lickona, T. (2013). Educating for character. how our school can teach respect and responsibility. Jakarta: PT Bumi Aksara.

Majid, A. (2012). Perencanaan pembelajaran mengembangkan standar kompetensi guru. Bandung: PT Remaja Rosdakarya.

Marsigit. (April 2013). Pendidikan karakter melalui pembelajaran matematika.
Makalah disajikan dalam Pidato Pengukuhan Guru Besar, di Universitas Negeri Yogyakarta.

Nucci, L. P., \& Narvaez, D. (2008). Handbook of moral and character education. Madison Ave: Rouledge.

Pala, Aynur. (2011). The need for character education. International Journal Of Sosial Sciences and Hunamity Studies, Vol 3 No. 2, ISSN: 1309-8063.

Republik Indonesia. (2003). Undang-undang Republik Indonesia Nomor 20 Tahun 2003 tentang Sistem Pendidikan Nasional

Republik Indonesia. (2007).Undang-Undang RI Nomor 17, Tahun 2007, tentang Rencana Jangka panjang Nasional Tahun 20052025.

Republik Indonesia. (2010). Kebijakan Nasional Pembangunan Karakter Bangsa Tahun 2010-2025.

Retnawati, H. (2015). Analisis kuantitatif instrumen penelitian (panduan peneliti, makasiswa, dan psikometrian). Yogyakarta: Parama Publishing.

Mustofa, S. (Mei 2014). Dilema pendidikan nasional. Kompas, hlm 4.

Sanjaya, W. (2012). Perencanaan dan desain sistem pembelajaran Edisi Pertama. Jakarta: Prenada Media Group

Santrock, J. W. (2014). Adolescence fifteenth edition. New York: McGraw-Hill Education.

Steinmetz, A. (2002). The discrepancy evaluaton model. Dalam Stufflebeam, D.L., Madaus, G.F., \& Kellaghan, T., Evaluation Models Viewpoints on Educational and Human Services Evaluation Second Edition. New York: Kluwer Academic Publisher.

Stufflebeam, D. L. (2002). The CIPP model for evaluation. Dalam Stufflebeam, D.L., Madaus, G.F., \& Kellaghan, T., Evaluation Models Viewpoints on Educational and Human Services Evaluation Second Edition. New York: Kluwer Academic Publisher.

Sulistyowati, E. (2012). Implementasi kurikulum pendidikan karakter. Yogyakarta: PT Citra Aji Parama. 
Jurnal Riset Pendidikan Matematika, 4 (2), 2017 - 165

Indah Pertiwi, M. Marsigit

Walikota Yogyakarta. (2011). Peraturan Walikota Nomor 60, Tahun 2011, tentang pengembangan pendidikan karakter pada satuan pendidikan.

Widyaningsih, T., Zamroni, Z., \& Zuchdi, D. (2014). Internalisasi dan aktualisasi nilai- nilai karakter pada siswa SMP dalam perspektif fenomenologis. Jurnal Pembangunan Pendidikan: Fondasi dan Aplikasi, $2(2)$. doi:http://dx.doi.org/10.21831/jppfa.v2i2. 2658 